\title{
Development of Syringe/Bottle Hybrids for Sampling Slurries
}

by

C. J. Coleman

Westinghouse Savannah River Company

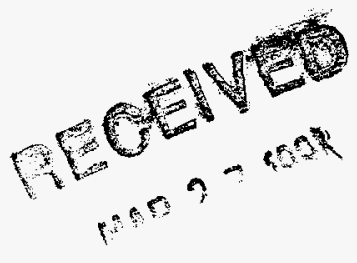

Savannah River Site

Aiken, South Carolina 29808

\section{INFORMATION ONLY}

This paper was prepared in connection with work done under the above contract number with the U. S. Department of Energy. By acceptance of this paper, the publisher and/or recipient acknowledges the U.S. Government's right to retain a nonexclusive, royalty-free license in and to any copyright covering this paper, along with the right to reproduce and to authorize others to reproduce all or part of the copyrighted paper. 


\section{DISCLAIMER}

This report was prepared as an account of work sponsored by an agency of the United States Government. Neither the United States Government nor any agency thereof, nor any of their employees, makes any warranty, express or implied, or assumes any legal liability or responsibility for the accuracy, completeness, or usefulness of any information, apparatus, product, or process disclosed, or represents that its use would not infringe privately owned rights. Reference herein to any specific commercial product, process, or service by trade name, trademark, manufacturer, or otherwise does not necessarily constitute or imply its endorsement, recommendation, or favoring by the United States Government or any agency thereof. The views and opinions of authors expressed herein do not necessarily state or reflect those of the United States Government or any agency thereof.

This report has been reproduced directly from the best available copy.

Available to DOE and DOE contractors from the Office of Scientific and Technical Information, P. O. Box 62, Oak Ridge, TN 37831; prices available from (423) 576-8401.

Available to the public from the National Technical Information Service, U. S. Department of Commerce, 5285 Port Royal Road, Springfield, VA 22161. 


\section{DISCLAIMER}

Portions of this document may be illegible electronic image products. Images are produced from the best available original document. 
Westinghouse Savannah River Company

Savannah River Technology Center

WSRC-TR-97-386

Page 1 of 16

Rev. 0

January 8, 1998

Keywords:

Improved Sampling, DWPF Sampling,

Heterogeneous Slurries

TO: $\quad$ A.L. Blancett, 773-A

FROM: C.J. Coleman, 773-A

\section{Development of Syringe/Bottle Hybrids For Sampling Slurries (U)}

Distribution:

R.S. Beck, 704-28S

S.L. Marra, 704-28S

J.N. Brooke, 773-A

J.F. Ortaldo, 704-S

P.F. Cloessner, 773-A

C.T. Randall, 704-T

J.W. Clymire, 773-A

W.C. Sexton, 773-A

P.T. Deason, 773-A

R.B. Spencer, 210-S

H.H. Elder, 704-S

W.A. Spencer, 773-A

S.D. Fink, 773-A

K.R. Wells, 210-A

P.D. Fledderman, 735-A

J.W. Wilson, 210-A

R.P. Kemmerlin, 735-A

R.H. Young, 735-A

STI -703-43A 
Westinghouse Savannah River Company

Savannah River Technology Center

January 8, 1998
WSRC-TR-97-386

Page 2 of 16

Rev. 0

Keywords: Improved Sampling, DWPF Sampling, Heterogeneous Slurries

TO: $\quad$ A.L. Blancett, 773-A

FROM: C.J. Coleman, 773-A

\section{Development of Syringe/Bottle Hybrids For Sampling Slurries (U)}

\section{Summary}

A convenient and effective sample bottle system based on simple modifications of disposable plastic syringes and bottles has been devised and tested for slurry samples. Syringe/ bottle hybrids (hereafter referred to as syringe bottles) have the convenience of regular flat-bottom bottles with screw cap closures. In addition, the syringe imparts a sliding and adjustable bottom to the bottle that forces the entire contents from the bottle. The system was designed especially to collect samples for high temperature work-ups of DWPF slurry samples. The syringe bottles together with fixed-bottom sample vial inserts (1) would provide the DWPF with convenient and reliable methods for dealing with slurry samples.

The primary advantages of the syringe bottles are:

- Slurries are transferred essentially quantitatively to crucibles without rinse water. Since no rinse water is required, converting $2-3 \mathrm{ml}$ of slurry into calcined feed by heating at $600-700^{\circ} \mathrm{C}$, or into glass by heating at $1100^{\circ} \mathrm{C}$ takes only about one hour. In comparison, $10-12$ hours are required when a $14 \mathrm{ml}$ glass vial is rinsed with a large volume of water to ensure quantitative transfer.

Interest in vitrifying melter feed for analysis has been revitalized by rapid, convenient methods to dissolve glass developed in the Analytical Development Section (details of these developments will be discussed in reports to be issued later). Experiments have shown that glass shards may be easily dissolved with alkali fusion methods if the fusion temperature is high enough to reach the softening point of glass (temperatures of 725$750{ }^{\circ} \mathrm{C}$ have been effective for DWPF-type glasses tested thus far). This development 
WSRC-TR-97-386

Page 3 of 16

Rev. 0

means that crushing glass to a fine powder, a tedious and time-consuming step to perform in the shielded cells, would be obviated. If $\mathrm{CsOH}$ is used as the alkali fusion reagent, determinations of $\mathrm{Na}$ and $\mathrm{K}$ are also possible. $\mathrm{CsOH}$ fusions of glass shards provide solutions that can be analyzed for all the elements needed for DWPF process control. Moreover, since no rinse water is needed to transfer the slurry to a crucible, the weight $\%$ solids measurements after simple drying and after vitrifying the melter feed can be combined with the dissolution by simply weighing the dry powder and glass before starting the dissolution. This simplified scheme would allow three of the most important process control analyses to be performed on one $2.5 \mathrm{ml}$ sample.

Another advantage of this scheme is that the alkali fusion dissolution can be used with $\mathrm{HNO}_{3}$. The problems inherent with using halide acids ( $\mathrm{HF}$ and $\mathrm{HCl}$ ), including precipitation of insoluble metal fluorides and corrosion of shielded cell surfaces and equipment, would be avoided. The cascading advantages of this approach are important for the DWPF Laboratory and start with the syringe bottle providing a sample that can be vitrified in one hour to yield $1.5 \mathrm{~g}$ of glass for analysis.

- The adjustable bottom of the syringe allows the sample volume to be easily controlled, an important analytical advantage for slurry samples that may be corrupted by subsampling.

- Difficulties of working around zirconium inserts during alkali fusion dissolutions are eliminated by using a syringe bottle to dispense the slurry.

- Syringe bottles are easy and inexpensive to fabricate. The syringes cost about 25 cents apiece and are fitted into the necks of plastic scintillation vials that cost about 15 cents apiece. A syringe bottle can be made by hand in about 10 minutes and is reusable.

- The septum caps that fit on the $14 \mathrm{ml}$ glass vials used for many years to collect Canyon samples at SRS also fit on inexpensive plastic scintillation vials. A sampling system in which scintillation vials are used to hold regular fixed-bottom inserts, to hold syringes, or to collect about $22 \mathrm{ml}$ of sample could be adopted, thus eliminating the need for 14 $\mathrm{ml}$ glass vials. Since plastic vials are less expensive than $14 \mathrm{ml}$ glass vials, a significant cumulative cost savings would be realized by using the scintillation vial system.

- A rubber stopper holder for the syringe bottles was designed that allows cell operators working with manipulators to dispense slurries into crucibles cleanly and conveniently. 
The concept of using a syringe to sample heterogeneous slurries will have applications beyond SRS. Transferring a slurry sample without corrupting its composition is often not trivial. A syringe, because it can dispense essentially the entire sample without using rinse water, is perhaps a unique implement to perform this operation. By simply cutting off the syringe end that normally accommodates a needle, a wide opening is created through which slurries pass unimpeded. To make a practical syringe sample container, the opening is fitted with screw threads to make a true bottle opening that can be sealed with a cap or attached to a process line for collecting a sample.

\section{Recommendations}

- A statistically designed study to compare the composition of samples taken in syringe bottle samples versus $14 \mathrm{ml}$ glass vial samples with a Melter Feed sampling loop should be performed to optimize the size of the syringe bottle. Syringe bottles would then be available for DWPF process samples.

- Syringe bottles may have applications for collecting high-activity waste tank samples. The advantages of syringe bottles for tank dip bottles are their low cost (about $\$ 1$ for a $60 \mathrm{ml}$ disposable syringe versus $\$ 100$ for a steel bottle) and their ability to dispense the entire slurry sample without corrupting the composition. SRS Waste Management should test the syringe bottle concept for tank dip samples if the benefits outweigh the aggravation of changing the sampling system.

- Environmental monitoring groups should consider possible applications of syringe bottles when samples contain a mixture of solids and liquids.

\section{Introduction}

DWPF samples are susceptible to analytical errors unless care is taken to avoid corrupting the sample composition. The mixtures of frit and sludge in the Slurry Mix Evaporator (SME) and Melter Feed Tank (MFT) are most prone to errors because the dense frit particles have different fluid dynamic properties than the smaller sludge particles. Removing a sub-sample without corrupting the composition from the standard $14 \mathrm{ml}$ sample vial requires not only excellent mixing in the vial, but also a system for transferring the sample to the analysis container. Performing accurate sub-sampling in a remote shielded cell environment was considered to be too technique dependent for routine use. Alternative approaches were sought to minimize sampling errors. 
Sample vial inserts (1) ensure that the entire sample is analyzed, thus eliminating the subsampling step altogether. A pre-weighed removable insert is placed in the vial neck so that the insert is filled rather than the entire vial. The insert after sampling is then simply decanted into a pre-weighed vessel so that the sample weight can be determined. The vial insert approach to sampling is a convenience breakthrough for cell operators working with manipulators in comparison to the traditional but tedious operations of mixing slurries, sub-sampling slurries, and rinsing out vials.

Experiments performed at SRTC and the DWPF showed that when an adapter was used on the Hydragard ${ }^{\mathrm{TM}}$ valve needle to minimize the penetration into the insert, $3 \mathrm{ml}$ inserts (only about $2.5 \mathrm{ml}$ of sample is actually collected because the Hydragard ${ }^{\top \mathrm{M}}$ valve needle occupies some of the insert volume) yielded samples that were statistically equivalent in composition to $14 \mathrm{ml}$ vial samples (2-6).

Most analyses and sample preparations required for DWPF samples are unaffected by the presence of a Teflon insert in the container. However, a Teflon insert does present a problem for high temperature work-ups such as alkali fusion dissolutions or vitrification of the melter feed. Teflon burns at the $600-725^{\circ} \mathrm{C}$ temperatures needed for fusions, making them impractical to use for fusion dissolutions. Rinsing the insert with water and then removing it is possible, but many hours would be added to the analysis to evaporate excess water before vitrifying or calcining the melter feed.

Zirconium inserts withstand the fusion temperatures so they can remain in the crucible. The problem with having a zirconium insert in the crucible at the time of the fusion is the possibility that the molten flux will not reach dried sample in the recesses of the insert. The cell operator has to remove the crucible from a hot muffle furnace, swirl the crucible to ensure that the flux reaches all surfaces of the insert, and then place the crucible back in the muffle furnace for additional heating. This technique-dependent step should be avoided if possible. Although more alkali flux could be added to ensure that the flux covers the entire insert, solutions with high alkali concentrations degrade the performance of ICP spectrometers. Zirconium is compatible with the temperatures needed for fusions, but cannot withstand the $1100^{\circ} \mathrm{C}$ temperture needed to vitrify the melter feed. A better solution to the problem of high-temperature dissolutions and vitrifications was sought.

Syringes are rarely, if ever, considered for sampling slurries. However, by simple modifications of inexpensive plastic syringes and bottles, effective DWPF process sample bottles were devised. A $10 \mathrm{ml}$ plastic disposable syringe can be cut off so that it has nearly the same dimensions as $3 \mathrm{ml}$ inserts. The most important advantage of syringe bottles is that the sliding bottom dispenses slurry samples into crucibles without rinse water for rapid high-temperature sample preparations. The development and proposed applications of syringe bottles as slurry collection devices are discussed in this report. 


\section{Discussion}

\section{Fabrication of Syringe Bottles}

Syringe bottles are not commercially available (or not to my knowledge). However, homemade versions are easy and inexpensive to make for DWPF applications using disposable syringes, plastic scintillation vials, and a few inches of both electrical and Teflon tape. A $10 \mathrm{ml}$ syringe has nearly the same inner diameter $(0.54 \mathrm{inch})$ as the fixedbottom $3 \mathrm{ml}$ inserts $(0.57 \mathrm{inch})$. By cutting off the syringe barrel at the proper length $(0.71$ inch, or so), a $3 \mathrm{ml}$ insert with a sliding bottom is made. The thrust of the testing program would be to determine the optimum size of the syringe bottle that would yield samples with statistically the same composition as those taken in $14 \mathrm{ml}$ vial samples. It is anticipated that the prototype syringe bottles will provide the same sample composition as the $3 \mathrm{ml}$ fixed-bottom inserts already tested. Any modifications to the syringe depth would be slight.

The entire syringe plunger can be left in the barrel to dispense the sample in the normal syringe mode. However, the plunger shaft is too long when pulled back to be compatible with the current DWPF sample vial holder. To solve this problem, the plunger shaft was cut off with a tubing cutter just behind the retainer ring that keeps the plunger from sliding out the barrel when pulled back (this retainer ring also securely locks the plunger in the barrel when the Hydragard ${ }^{\mathrm{TM}}$ valve is opened). The plunger is now only about 0.5 inch long. Before pushing the plunger back in the syringe barrel, the plunger was wrapped completely with a few inches of 0.75 inch wide Teflon tape to make the plunger chemically inert and to resist wetting better than the soft plastic plunger tip. The syringe plunger is now a small Teflon-covered plug. The Teflon tape also improves the seal with the syringe barrel (weight tests with liquid samples indicate that the barrel seal is so good that no evaporative losses occur). A reusable detached plunger is then used to engage the Teflon plug and dispense the sample.

Although using a detached plunger may at first seem inconvenient compared with using the normal integral plunger, there are several advantages with this arrangement. Since the composition of melter feed samples depends on vial insert volume and the depth of penetration of the Hydragard ${ }^{\mathrm{TM}}$ needle into the insert, the plunger position must be fixed at the optimum depth. The plunger plug is hidden in the syringe barrel, so there is little chance of the depth being accidentally altered. Another arivantage is that the flat botiom mears that the syringe can be sei down upright and handled with the convenience of a bottle. Figure 1 shows an exploded view of the syringe and scinillation vial at each stage of assembling a syringe bottle. Figure 2 shows a syringe bottle, a $3 \mathrm{ml}$ Teflon insert, and a $14 \mathrm{ml}$ glass vial to indicate the approximate relative size of the sample containers. 
WSRC-TR-97-386

Page 7 of 16

Rev. 0

To make disposable syringes into a practical DWPF sampling system, holders were made by using the screw threads on plastic scintillation vials. The vials are cut in half so that a syringe can be pushed into the neck of the vial to create a syringe/bottle hybrid. Use of scintillation vials as holders was possible because the septum caps that fit on $14 \mathrm{ml}$ glass vials also fit perfectly on scintillation vials. The outer diameter of the syringe barrel is slightly narrower (about 0.03 inch) than the inner diameter of the scintillation vial neck. The barrel was built up to make a very tight fit by using 3-4 revolutions of electrical tape. A few drops of household glue were added to the tape to make the bond with the vial even stronger. Construction is strong enough to require pliers to separate the syringe from the bottle.

Syringe bottles made from disposable syringes and scintillation vials would cost only about 40 cents for the syringe and bottle plus whatever labor costs are assessed for fabrication. Although the syringe bottles will be inexpensive enough to discard after a single use, the bottles can be reused indefinitely to save money and minimize waste. The syringe barrels are scrubbed completely clean by the Teflon-covered plunger. However, it may be awkward to "reload" the plunger back in the proper position in the barrel while using a manipulator. A practical compromise would be to reuse the syringe bottles but replace the Teflon-covered plunger after each use. A batch of used syringe bottles occasionally would be transferred to a hood where a new plunger would be inserted in each barrel using gloved hands.

Should syringe bottles be adopted by the DWPF for routine use, it is likely that they will be made off-site. The syringe bottle could be assembled from disposable syringes and scintillation vials jusi as they are now. A small machine shop would be suitable for cutting the syringes and vials and assembling them into syringe bottles. If syringe bottles are fabricated from scratch with screw threads integral with the barrel, then SRS would contract a commercial syringe manufacturer.

\section{Coupling the Syringe Bottle with a Crucible}

The most challenging aspect of the syringe bottle application was to develop a convenient way for the sample to be dispensed into a crucible while using manipulators (the normal finger grip used with a syringe would be too cumbersome). A simple, effective design was based on a \#10 rubber stopper (Figure 3). The rubber stopper was ideal because its tapered, flexible side fits snugly inside both $50 \mathrm{ml}$ zirconium and platinum crucibles. The snug fit allows the pre-weighed crucible to the placed over the rubber stopper so they can be flipped over for dispensing the sample. 
The rubber stopper was first drilled with a hole about 1.05 inches in diameter at the narrow end to accommodate the syringe bottle. This hole was about 0.70 inches deep to provide a friction fit of the rubber stopper around the syringe bottle. The depth of this hole is important to the success of the syringe bottle because it positions the bottle opening less than 0.5 inch from the crucible bottom. When the coupled syringe bottle and crucible are flipped over, the proximity of the syringe bottle to the crucible bottom ensures that the slurry is deposited as a neat pool in the crucible bottom with no special technique required. A second smaller hole about 0.50 inches in diameter was drilled into the wide end of the rubber stopper. This hole accommodates the detached plunger for pushing the sample through the syringe barrel.

The entire sampling sequence would proceed as follows:

1. A syringe bottle with a septum cap is placed in the 1.05 inch diameter hole drilled in the narrow end of the \#10 rubber stopper. This step would probably be done in a hood in the DWPF Laboratory. Several syringe bottle/rubber stopper assemblies would be transferred to the DWPF sampling cell to collect the replicate Melter Feed or Slurry Mix Evaporator samples.

2. Syringe bottles are filled just as inserts or $14 \mathrm{ml}$ glass vials are filled now. The septum caps are replaced with solid caps. The syringe bottle/rubber stopper assemblies are transferred from the sampling cell to the analytical cells.

3. A syringe bottle is uncapped and a pre-weighed crucible placed over the rubber stopper to make a snug friction fit.

4. The coupled rubber stopper and crucible are inverted and the crucible set on the shielded cell floor. The hole in the bottom of the rubber stopper is now accessible.

5. The detached plunger is placed in the 0.5 inch diameter hole in the rubber stopper and used to push the Teflon plug through the syringe barrel to dispense the sample into the crucible bottom. The detached plunger is made with a stop on the shaft so that the plunger tip extends just beyond the bottle opening to dispense all the sample but the tip stays in the syringe barrel.

6. The rubber siopper containing the empty syringe bottle is de-coupled from the crucible. About $2.5 \mathrm{ml}$ of slurry is now in the crucible bottom and ready to be weighed, dried, vitrified, and dissolved.

Steps 3-6 can be performed in about 30 seconds. The speed and convenience of this cell operation rivals that of decanting Teflon or zirconium inserts into analytical vessels. 


\section{Fusion Dissolutions of Glass Samples Versus Calcined Melter Feed Samples}

The syringe bottle method of dispensing a small sample of melter feed into a crucible makes it fast and easy to convert the slurry into either glass or calcined feed. The development of $\mathrm{CsOH}$ fusion of glass shards makes analyzing glass competitive with analyzing calcined feed. There are pros and cons for both approaches that merit discussion, but analyzing the glass would yield elemental analyses on a glass basis as required to fit the process control code.

The most important fundamental advantage of vitrifying the melter feed versus calcining it is that it reduces by a factor of six the amount of sample dissolved, thereby simplifying the alkali fusion. Vitrifying melter feed forms a thin pellet of glass weighing about 1.5 grams at the bottom of a platinum crucible. The pellet would be crushed in the platinum crucible into very small shards in a matter of a few seconds, probably by using a ceramic pestle or a blunt metal rod. About 0.25 grams of the glass shards would be transferred from the platinum crucible to a zirconium crucible and 2.5 grams of $\mathrm{CsOH}$ added to carry out the fusion.

In contrast, calcining the melter feed yields a heterogeneous mixture of dried sludge and frit. To avoid analytical errors, the entire 1.5 grams of calcined feed sample must be dissolved. Glass shards and calcined feed both dissolve readily, but the advantage of the smaller sample is that less alkali flux salt is required. To obtain the traditional 10:1 ratio of flux salt to sample, 15 grams of $\mathrm{CsOH}$ would be used. This quantity of fused salt takes longer to dissolve. Moreover, the additional salt makes it more difficult for the cell operator to know wher the salt has dissolved. There is a real potential for analytical errors if the sample is worked up before the alkali flux-sample mixture completely dissolves.

However, analyzing the calcined melter feed would have some operational advantages for the DWPF Laboratory. The most important is that there would be no need for maintaining high-temperature furnaces required to vitrify melter feed. Expensive platinum crucibles would not be needed to make glass. Calcining the melter feed also allows the entire workup to be performed in a single zirconium crucible. To make glass, the melter feed is first vitrified in a platinum crucible and then the glass shards transferred to a zirconium crucible (platinum reacts with alkali flux).

The DWPF Laboratory will have to weigh the pros and cons of analyzing glass versus calcined melter feed should this approach be adopted. Based on my laboratory experiences with both approaches to date, I would make and analyze the glass primarily because the alkali fusions of the smaller glass samples are smoother than the scaled-up fusions required for the calcined feed. 


\section{DWPF Process Sample Bottles Based Exclusively on Plastic Scintillation Vials}

The fact that septum caps that fit $14 \mathrm{ml}$ glass vials also fit plastic scintillation vials could make the glass vials obsolete in the DWPF. The scintillation vials are made from high density polyethylene and cost only about 15 cents each versus about 5 dollars for glass viais. Scintillation vials are superior holders for regular fixed-bottom inserts as well as the syringe application previously described in this report. In addition, the $22 \mathrm{ml}$ volume of scintillation vials would reduce the number of full-vial samples needed to collect enough samples for analyses such as weight percent solids in filtered samples. The money saved by using scintillation vials instead of $14 \mathrm{ml}$ glass vials to collect samples may seem insignificant compared to the total DWPF operation cost, but the cumulative savings over 25 years of DWPF sampling would be more impressive. I can think of no technical advantage of using a $14 \mathrm{ml}$ glass vial instead of a $22 \mathrm{ml}$ plastic vial to collect samples, so $s w i t c h i n g$ to an inexpensive plastic vial sample collection system seems appropriate.

\section{Tests of Syringe Bottles in the Thermal Fluids Laboratory}

The melter feed sampling loop and Hydragard ${ }^{\mathrm{TM}}$ valve in the Thermal Fluids Laboratory was used to mechanically test whether syringe inserts could hold up to the rigors of DWPF sampling. No problems were detected. The plunger retainer mechanism in disposable plastic syringes is so secure that it is unlikely that a redundant stop would be required to keep the plunger from being forced out when the Hydragard is opened. In fact, several tests were performed in which the syringe plunger was not pulled all the way back to the stop. The friction fit of the syringe plunger in the barrel was tight enough that the force of the flowing slurry did not change the plunger position.

\section{Syringe Bottles Allow Sample Volume Flexibility}

An advantage of using modified disposable syringes for sample containers is that the sample volume can be easily set by cutting off the syringe to the desired length or by adjusting the plunger depth in the syringe barrel. In contrast, the volume of commercially available plastic bottles may not be convenient for analysis. Control of sample volume is useful for all samples, but is especially important for slurries because analyzing the entire sample eliminates sub-sampling errors.

\section{INFORMATION ONLY}




\section{Possible Applications of Syringe Bottles as SRS Waste Tank Dip Bottles}

Disposable $60 \mathrm{ml}$ plastic syringes can be made into prototype large syringe bottles by using the screw threads from a $125 \mathrm{ml}$ plastic bottle (Figure 4). Syringe bottles this large suggest the possibility that they could replace the $100 \mathrm{ml}$ steel bottles used for taking dip samples in SRS High Level Waste Tanks. The syringe bottle would likely be placed into a metal sleeve that would attach to dip sample lines analogous to the $100 \mathrm{ml}$ steel bottles. The syringe bottle would then be removed from the sleeve and sent to the SRTC Shielded Cell Facility for analysis. The primary advantage of the syringe dip bottle is that the entire contents would be dispensed into an analytical container. Dip bottles sent to SRTC occasionally contain slurries that are so viscous that they cannot be emptied easily into an analytical container. Merely shaking the bottle is inadequate to ensure that a representative sample is removed. Note in Figure 4 that transferring a slurry sample from the syringe bottle into a larger analytical bottle to permit adequate mixing is made convenient with a homemade adapter. Two- $125 \mathrm{ml}$ bottle caps were cored out to leave only the cap threads (no top). The caps were then joined back-to-back with tape to make the adapter. The syringe bottles for this application would also use a non-integral plunger so that the plunger shaft would not extend awkwardly from the syringe barrel. Plastic syringes would be significantly cheaper (about $\$ 100$ cheaper) than steel bottles. Another advantage is that the translucent syringe bottle would indicate whether sample is actually in the bottle before being sent to SRTC for analysis (7).

Disadvantages of the syringe bottle include the fact that more samples may be required to compensate for the $60 \mathrm{ml}$ volume of syringes versus the $100 \mathrm{ml}$ bottles. Also, the $60 \mathrm{ml}$ syringes are taller than $100 \mathrm{ml}$ bottles, meaning that they might not fit in the current doorstop size. Waste Management would have to consider the pros and cons of changing the sample bottle.

\section{General Applications of Syringe Bottles}

Problems encountered with collecting and dispensing slurry samples are not unique to the DWPF and SRS. Many manufacturing processes generate slurry samples that must be analyzed for process or quality control. Unless a method is in place to analyze the entire sample, errors due to sample heterogeneity may occur. Moreover, throughout the world thousands of environmental samples are taken each day. Many of these samples contain solids or sedirrents thai must be suspended and accurately sub-sampled to avoid analytical errors. Syringes bottles offer a convenient way to collect and transfer samples containing solids quantitatively without error. If syringe bottles were commercially available, analytical chemists would likely find more applications for them. 


\section{Acknowledgments}

I would like to acknowledge Curtis Sexton in the SRTC Glass Shop for his skill and patience while making the rubber stopper holders for the syringe bottles. Curtis suggested that freezing the soft rubber stoppers with liquid nitrogen would provide an easier substance to drill. Curtis also fabricated holders to make accurate drilling of the stoppers possible.

I would also like to thank Joe Clymire for his help on several versions of the syringe bottle holders.

\section{References}

1. C.J. Coleman and S.R. Goode, "DWPF Sample Vial Inserts", WSRC-TR-95-205, May 31, 1995.

2. R.S. Beck, C.J. Coleman, W.A. Spencer, and J.L. Steimke, "Results of Scoping Work for Insert Use at DWPF', WSRC-TR-97-76.

3. S.P. Harris, 'DWPF Sample Vial Insert Study,-Statistical Analysis of Parametric Data", SRT-SCS-970006 (Rev.1) March 10, 1997. Later this same document was assigned the permanent document number WSRC-TR-98-00018, January, 1998.

4. R.S. Beck, "Review of Statistical Analyses Resulting from Performance of HLWDDWPF-005, WSRC-RP-97-883, Sept.29, 1997.

5. S.P. Harris, "DWPF Sample Vial Insert Study-Statistical Analysis of DWPF Mock-up Test Data, WSRC-TR-97-00292, September 18, 1997.

6. C.P. Reeve, "Covariance Matrices for Direct Dissolution of Vial Insert Samples in DWPF Mock-up Facility”, WSRC-TR-97-00286, September 24, 1997.

7. S.D. Fink, Personal Communication, 1997. S.D. Fink commented that the translucent body of the syringe would allow operators to confirm that sample is in the bottle before sending the sample to the laboratory for analysis. 


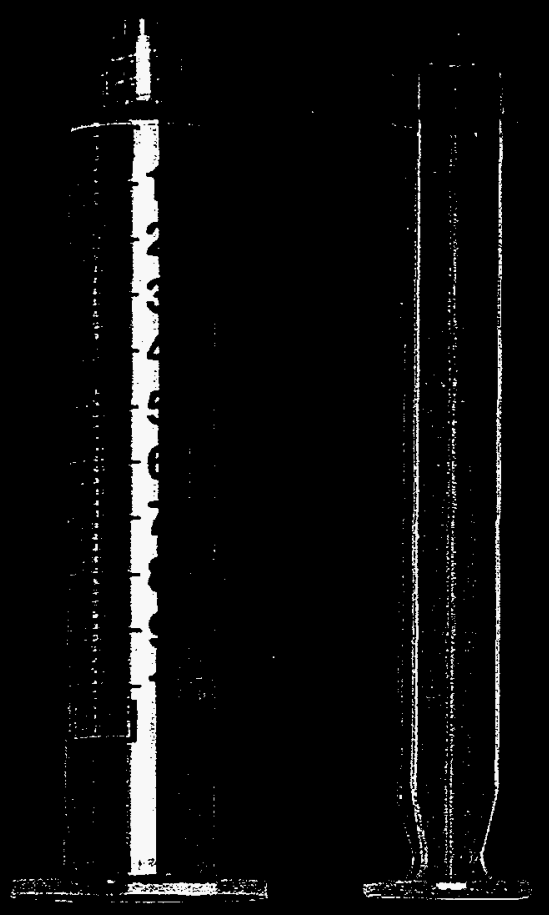

vilo
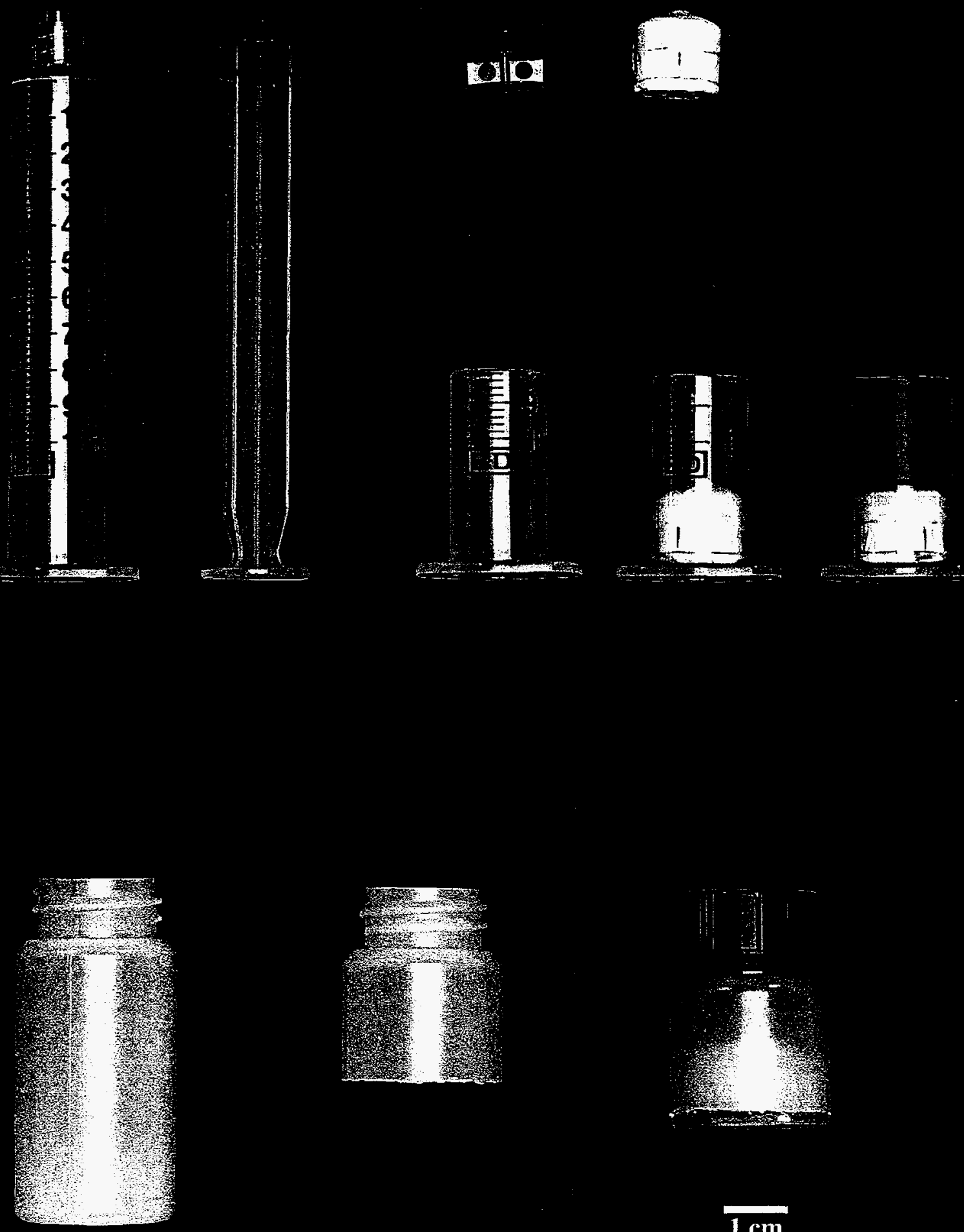

$1 \mathrm{~cm}$

Figure 1

Exploded View of Syringe and Scintillation Vial Showing Steps of Syringe Bottle Fabrication 

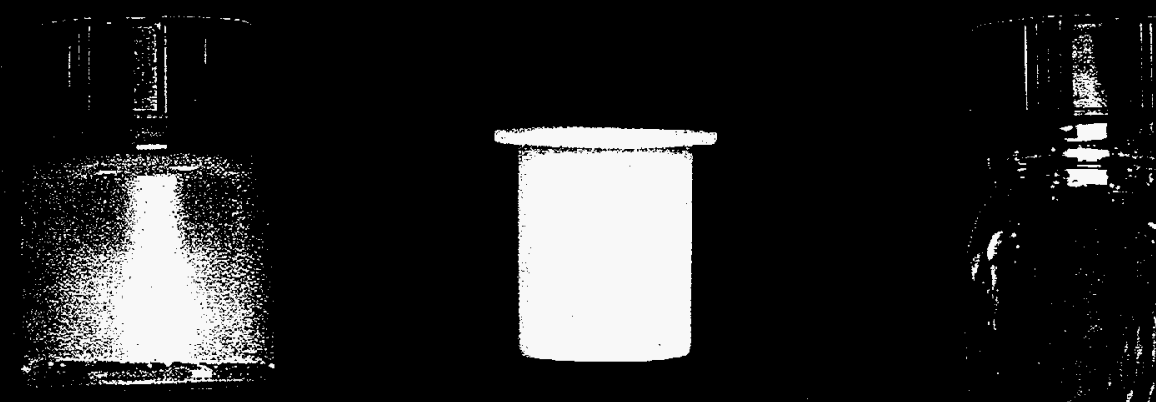

$1 \mathrm{~cm}$

(a)

(b)

(c)

Figure 2
(a) Syringe Bottle
(b) Teflon Insert
(c) $14 \mathrm{ml}$ Glass Vial 

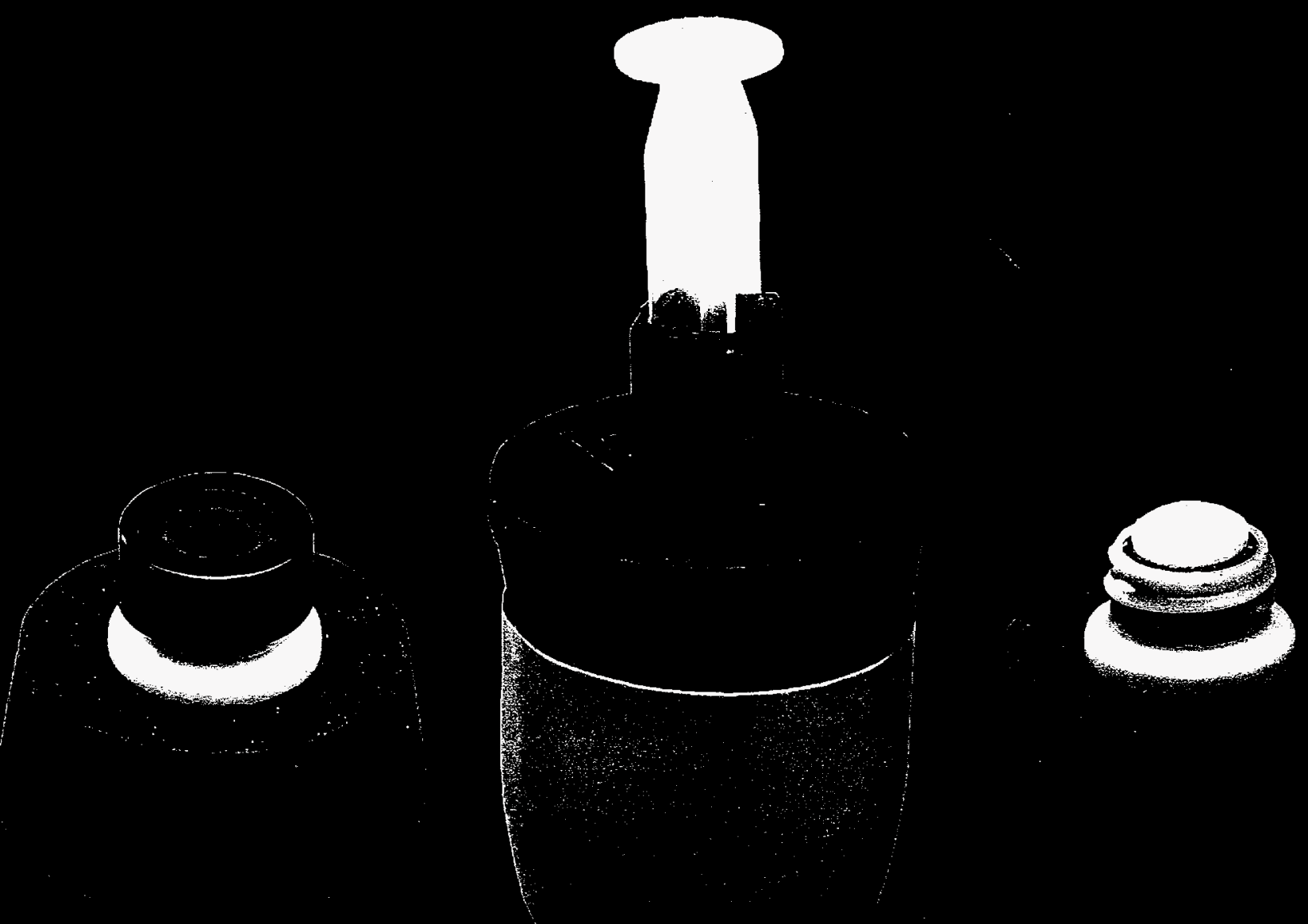

(a)

(b)

\section{Figure 3}

(a) Syringe Bottle in Rubber Stopper Holder

(b) Coupled Syringe Bottle and $50 \mathrm{ml}$ Crucible

(c) Teflon Plunger Protrudes from Syringe Barrel to Dispense Sample 


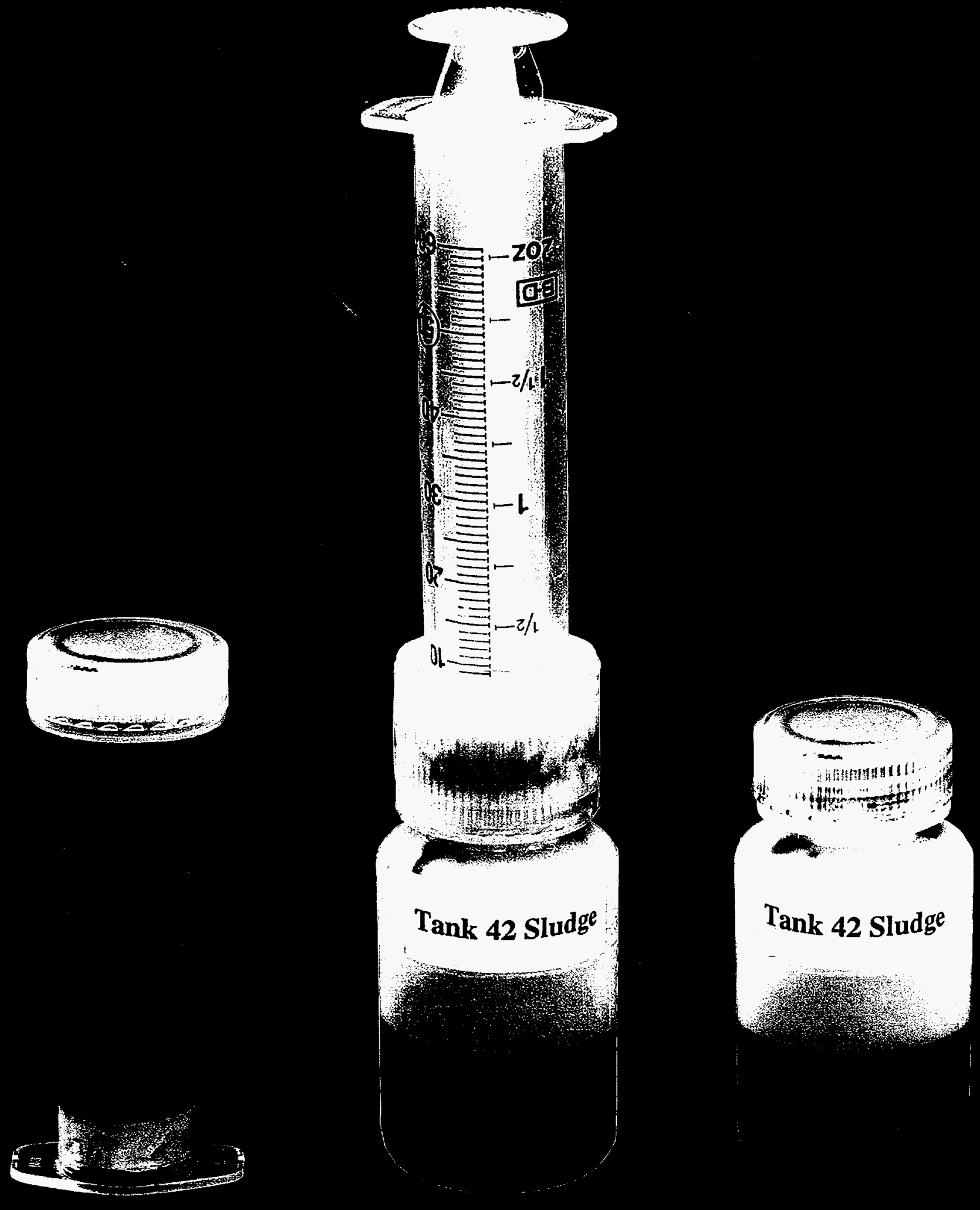

Figure 4

\section{$60 \mathrm{ml}$ Syringe Bottle Transfer of Sludge to a $125 \mathrm{ml}$ Plastic Bottle}

